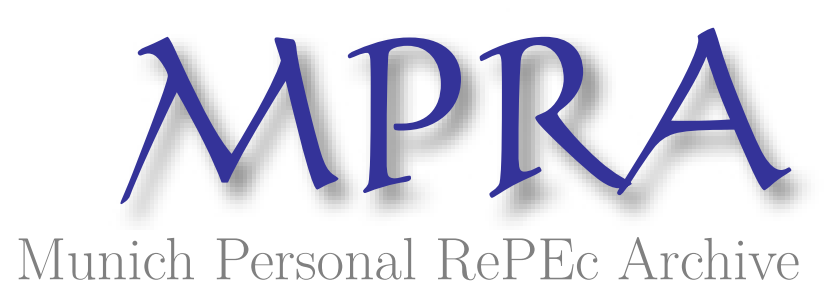

\title{
The Transformation of Rural Labour Systems in Colonial and Post-Colonial Northern Nigeria
}

Kohnert, Dirk

GIGA - German Institute of Global and Area Studies / Institute of African Affairs

1986

Online at https://mpra.ub.uni-muenchen.de/5722/

MPRA Paper No. 5722, posted 14 Nov 2007 06:00 UTC 


\title{
The Transformation of Rural Labour Systems in Colonial and Post-Colonial Northern Nigeria
}

\author{
Dirk Kohnert ${ }^{1}$
}

\begin{abstract}
:
The study attempts to highlight the interrelation between three central points in the ongoing debate on the political economy of development: viability, surplus, and class-formation. A case study of the development of rural labour systems in Northern Nigeria is meant to provide both a better qualitative and quantitative idea of this interrelation. After an analysis of the socio-economic effects of forced and bonded labour during colonial times, the articulation of different systems of family and non-family labour has been investigated. Class-specific effects of labour and capital input do even result in an increasing use of communal labour by rich and middle peasants after the Nigerian Civil War: its form remains, but its content changes fundamentally. The socio-economic and material base for small-scale peasant subsistence production has been gradually destroyed.
\end{abstract}

Keywords: political economy of development; labour systems; rural areas; economic history; Africa; colonialism; Nigeria

JEL-Code: F54; J21; J43; J61; J71; J81; J83; K31; N37; P16; P48; P52; Z13

\footnotetext{
${ }^{1}$ Authors version of publication: Kohnert, Dirk (1986): The transformation of rural labour systems in colonial and post-colonial northern Nigeria. In: Journal of Peasant Studies, vol. 13 (1986) 4: 258-271.
} 
'It was not the intention of the Government to interfere with the institution of domestic slavery vi et armis but gradually substitute a better form of labour contract.' (Lugard, in Annual Colonial Report for 1901, p. 5)

When the troops of the Royal Niger Company (RNC) under G. Goldie took Bida by a surprise raid in December 1896, the talakawa, that is, the commoners of the Sokoto Caliphate might have hoped that this first military intervention of the white man against their rulers would indicate the end of centuries of oppression and exploitation by the ruling slave raiding class. It was probably not exaggerated when Goldie reported to the Foreign Office in 1897 that he was welcomed with a 'wild outburst of joy' in the areas which were hitherto subject to slave raiding. At least in the Nupe and Ilorin Province peasants threw off their yoke of serfdom immediately after the fall of Bida, left the slave plantations in tens of thousands and refused to pay tribute. In the following years the country was thrown into a condition of 'serious disorder and disintegration', as the British Resident at Bida put it [end of p. 258]: 
'The pagan towns west of the Kaduna had all thrown off their allegiance, and would acknowledge no authority of either Emir or Resident... farms were being deserted by the slaves and such was the state of unrest that cultivation had almost ceased. The Fulani ruling classes were rapidly becoming desperate at the state of the country' [NAK, BIDINA 6, B 655: 3].

However, this meant but a short relief to the peasantry. The British were at pains to regain the confidence of the ruling class, to establish 'law and order', and to secure both a steady flow of taxes and of labour to build up an infrastructure which could facilitate the surplus extraction from their colony. Lord Lugard, first Governor of Northern Nigeria, like Goldie, a former employee of the RNC, established a system of 'indirect rule' through the native administration, for which the Nigerian emirates should become famous in colonial history.

However, the native authorities, most keenly alive to the benefits of this new departure, were far from being a passive instrument in the hands of the British Residents. By a reinterpretation of their traditional power structure they succeeded - assisted and guided by colonial administrators - in concentrating and consolidating their grip on the peasants. This they did by a combination of measures in the military, political, economic, judicial and cultural field which have been discussed in detail elsewhere [cf. Kohnert, 1982: 91-144].

In the following I want to concentrate on problems caused by one aspect of colonial intervention into the mode of production of a West African society: $\bullet$ the transformation of the rural labour system. ${ }^{1}$ Rather than to inflate the growing body of literature on the marginal areas of our 'Lebenswelt' by yet another piece of grassroots research, this is meant to illuminate closely interrelated central points in the ongoing debate on the political economy of development: viability, surplus, class and exploitation.

\section{On the moral education of the peasantry}

Theory and practice of early colonialists, like Lord Lugard, seem to be especially suited to reveal with little disguise the ideological content of basic assumptions of neo-classical economic theory, which were mirrored in their views on 'the stages of tribal evolution' and 'civilisation' [cf. Berthoud, 1976: 34-5]. This ethnocentristic position not only took the social organisation of advanced capitalism in England as undisputable reference point for all other societies, it also tried, with all necessary force (quite contrary to its camouflage by liberal terminology), to 'educate' the primitive peasants 'of a low and brutal stamp ... [who] did not desire our rule or Fulani rule but no rule at all' [Lugard, Annual Colonial Report for 1903: 7] and who allegedly squandered their meagre surplus in 'frequent drunken orgies' [Lugard, 1923: 235, 603-4]. They should accept a more advanced social organisation, characterised by central authorities, law and order, recognition of private property - but, above all, the willingness to increase production and to maintain the position of their rulers. 
To effect this change, Lugard envisaged two major economic means: the introduction of a general system of taxation ${ }^{2}$ and of wage labour, 'for no country in the world [sic] can do without casual paid labour' [Lugard, 1923: 391].

The slave-owners at Sokoto or Yola were quick to recognise the profitability of the switch from slaves to hired labourers, provided they could get them cheap and in sufficient numbers: A free labourer could claim no more than his day's wage and the employer would neither be compelled to support him and his family in sickness or old age, nor would he have to cater for him during the dry season, when there was little work to do [cf. Lugard, 1923: 390-91, 4023]. The problem however was, as shown above, that the slaves did not seem to honour their obligations vis-a-vis their liberators, but run away and A wanted to take up their own farming. This the colonial administration had TM to check: as long as slaves would 'show initiative and a real love of freedom [sic] to engage themselves as free labourers' colonial and native opinion (as usual equated with the interest of the ruling class) was fairly satisfied [Lugard, 1923: 372-5; author's emphasis.] Otherwise they were refused legal protection by the Colonial government or were restricted in their access to land in collaboration with the Native Authority [cf. Annual Colonial Report for 1905/6: 49]. Besides, the freed slaves had to pay redemption money to their 'legal owner' ${ }^{3}$ if necessary, from their own wage, and the 'customary tribute' to their traditional chiefs. The latter practice, tolerated by the British, could make wage labour even more profitable [cf. Lugard, 1923: 295, 375]. As Mason [1978: 65] observed concerning the so-called 'political labour' used for the railway construction on the Baro-Kane Line: 'Plainly in the paternalistic scheme of the Resident, subjects had the clear obligation to resign their labour to the new colonial state and their wages to their traditional masters.' Whether this was the 'better form of labour contract' Lugard [Annual Colonial Report for 1901: 5] had in mind is not known, but the description of any form of labour relations as being founded on (social?) contracts is revealing. It assumes a balance of interest between employer and employee, negotiated by individuals in a free environment (market). This sounds quite familiar to us, as it is the standard formula of the subjectivist economic theory used also by some present-day sociologists to camouflage growing socio-economic injustice in the course of the dissolution process of the peasantry as 'self-exploitation' (cf. the critique of Chayanov and the other populists by Utsa Patnaik [1979]). The latter is not just tautological (any actual observation is an equilibrium point), but also forgets the crucial question concerning the historical genesis of the unequal resource position of master and worker, or patron and client, which forced the weaker part into such 'contracts'. Against the background of the described Nigerian conditions it seems to be obvious that a social scientist, who contents himself with analysis of the status quo, becomes necessarily an apologist of existing social structure and exploitation. 


\section{Forced - and bonded labour}

Despite the combined efforts of Colonial and Native Authority the supply of cheap paid labour did not meet the demand of either the British or the local rulers, and therefore the creation of transitional forms of labour organisation seemed to be imperative during the first three decades of colonial rule, namely forced labour for the British and bonded labour for the local elite. Forced labour, etun wájibi, in Nupe, or 'political labour', as the British called it, was employed mainly for porterage, ${ }^{4}$ mining [cf. Freund, 1981: 136-55], and the building of offices, roads, and the railway lines [cf. Mason, 1978]. Concerning the latter, official reports of the Colonial government noted that 'no single case of ill-treatment of natives has been reported' [Annual Colonial Report for 1910/11: 39, Appendix II] and boasted of having probably surpassed the world record in track laying with 6.5 miles in one day [ibid., 1907/8: $22 ; 1910 / 11: 41]$. But the humiliation and exploitation of the working force seemed also to have reached record levels. The official mortality rate, perhaps a reflection of the deplorable working conditions, stood at 24 deaths per thousand workers per annum [cf. Mason, 1978: 74].

At the same time severe famines, probably aggravated, if not caused, by the combined effects of forced labour and exorbitant tax demands, ${ }^{5}$ led to a sudden growth of bonded labour (sofa, in Nupe; jingina, in Hausa), that is, the pawning of one's own children or other relatives for debts [cf. Nadel, 1942: 311-12; Kohnert, 1982: 145-7]. In the second decade of Colonial rule pawning of human pledges was so prevalent, especially among the Nupe, that it was almost a recognised part of their social life. When the British finally suppressed this kind of investment in 'human capital' in 1933/34 it was already outdated; wage labour had been already firmly established.

\section{The development of rural hired labour}

The main motive in undertaking hired labour during the thirties in the Northern Emirates named by the peasants was invariably to obtain tax money, either for oneself or for the compound head [cf. Nadel, 1942: 252; Smith, 1955:161]. Given a minimum daily wage of 2 3d, a peasant had to work up to 90 days as hired labourer in Nupeland in 1934/35, to be able to meet the tax demand of $9 / 6$ to 15 sh. per male adult. These 90 days were equivalent to about 40 per cent [sic] of the total annual work-load of a Nupe peasant [cf. Kohnert, 1982: $126,155]$. It is not surprising, therefore, that this development coincided with severe food scarcity and famine, as well as a wave of Nupe emigration to the less heavily taxed provinces of Southern Nigeria [cf. Nadel, 1942:10/11]. But let us be clear about one thing, the poll tax was only one factor embedded in a closely knit fabric of several determinants of the dissolution process of the peasantry, especially the undermining of both subsistence production and the ecological balance by the drain of agricultural surplus (through direct and indirect taxation (marketing boards), tribute, etc.), increasing market orientation, and the changes in the administrative, judicial (for example, land tenure), political, and educational system [cf. Kohnert, 1982: 91 -144]. 
In addition it should be stressed that these factors had class-specific effects, that is, whereas some richer farmers definitely profited by these changes, the majority of the peasants had to suffer. The latter became especially clear during the great famines in Hausaland. A. Grove, one of the Agricultural Officers in the Colonial Service, reported of the famine in Katsina Province in 1949-51:

In Katsina Emirate ... food shortages were felt most keenly by the small hand-farmers with about 4 to 9 acres of land who form the majority of the population. Many of them ... sold their animals and in some cases their land too, worked as labourers in order to buy food ... Farmers with large numbers of cattle seem to have obtained quite good yields from their land in spite of the weather ... and had sufficient capital to pay labourers to cultivate their field later in the year. In fact, many of them benefited considerably from food-shortage. A certain trader in Bindawa was able to buy in 1950, 35 acres ... belonging to 8 different owners who are said to have taken the initiative in the transactions because they were sorely in need of cash [Grove, 1957: 21]

In Daura Emirate things were equally bad. The poor peasants neglected their own farms because they had to work as hired labourers during the growing season, when they earned just $4 \mathrm{~d}$. per day, one-eighth of the normal wage at that time of the year; they had to borrow money and seed from local merchants, and many were subject to growing indebtedness [Grove, 1957: 20-21]. Similar incidences were reported from the 1973 famine in Kano state [cf. Mortimore, 1973].

Whereas many poor farmers during the 1950s went on seasonal migration (cin rani in Hausa, that is, 'to eat away the dry season') local hired labour has been increasingly accepted in recent years (see Table 1). Migrant labour from the Northern Provinces drew the attention of Colonial officers for the first time in 1936; since then it rapidly increased in volume, reaching a peak in the early 1950s, when, for example, during the dry season of 1952, a total of 259,000 migrants were recorded in Sokoto Province alone, representing between a quarter and a third of the labour force of that province [cf. Prothero, 1957:254-5]. About half of these migrants were going to work as labourers, mainly in the cocoa belt of Southern Nigeria and Ghana, the tin mines of Jos Plateau, or the cash crop areas of the south-eastern districts of Sokoto Province. Another 24 per cent went as petty traders, especially to Eastern Nigeria [ibid.: 255-6]. The economic motive was shown to be the outstanding reason for migrating: the search for food and money for necessary purchases, and tax, combined with the growing inability of the poorer section of the rural population to feed themselves because of insufficient land or other means of production. The customary systems of land tenure broke down as a result, and the outright and increasingly open sale of land became an accepted practice [ibid.: 253]. However, as a result of economic and social reasons these large annual waves of seasonal migration apparently decreased in the past three decades, first, because of decreasing wage differentials between the North and the South. 
Table 1: Development of non-family labour use in four Nupe villages 1916-76 (percentage of households per village and year using specified kinds of labour)

\begin{tabular}{|c|c|c|c|c|c|}
\hline Village \& Year & upland & upland & fadama & fadama & total \\
\hline & Dabba & Lemu & Jima & Kuchi & \\
\hline & $\begin{array}{lll}\text { (1) } & \text { (2) (3) } \\
\end{array}$ & $\begin{array}{lll}(1) & (2) & (3)\end{array}$ & $\begin{array}{|lll|}(1) & (2) & (3)\end{array}$ & $\begin{array}{lll}(1) & (2) & (3)\end{array}$ & $\begin{array}{|lll|}(1) & \text { (2) } & \text { (3) } \\
\end{array}$ \\
\hline kwadago (a) & 142550 & 43885 & 226696 & 202590 & 143675 \\
\hline egbe (b) & 2532 & 372319 & 462852 & 456095 & 351927 \\
\hline dzoro (c) & 182731 & 213125 & 143442 & 358095 & 193538 \\
\hline
\end{tabular}

Note: (1) $1916 / 26 ; \quad$ (2) $1967 ;$ (3) $1975 / 76 \quad$ ( $\mathrm{n}=204)$

(a) hired farm labour; (b) communal farm labour; (c) exchange farm labour Source: Author's survey, 1976; for the methodology of data collection, see Kohnert, 'Klassenbildung im ländlichen Nigeria', Hamburg, 1982, pp. 34-61

Whereas in 1954, a Nupe migrant could earn up to ten times as much as a labourer in the cocoa belt, ten years later, the wages on the Yoruba cocoa or palm oil farms were only twice as high as in Bida Emirate. Second, growing commercialisation of agriculture in the North combined with (semi-)permanent rural- urban migration and the emerging social differentiation of the peasantry' provided for an increasing local demand for hired farm labour.

The description given so far of the dissolution process of the peasantry, that is, concentration of land in the hands of a few rich peasants, 'liberation' of the poor peasants, last and not least, from their own means of production, pauperisation, waves of migrant labourers looking desperately for food and money, may remind us of similar stages of primary accumulation in the rural areas of nineteenth-century Europe. This impression, however, must not blur our sight of strong countervailing tendencies, not so much 'natural' levelling forces, overstressed time and again by the Populists, as the often-mentioned 'death as the great leveller' or the drought in the Sahel region. As we have seen, rich peasants may not only have been able to shield themselves effectively against such disasters because they had better manured land, access to water sources, sufficient storage facilities, etc., but also because they could take advantage of the misery of their co-villager.

However, contrary to the comparable European development, much of the surplus extracted from the Nigerian peasantry was not ploughed back into agriculture, or at least in a home industry that could serve as a market for agricultural products, but was transferred to the colonial centres. In addition, the integration of the Nigerian economy into the world market, and the large productivity gap between agriculture in the advanced capitalist countries and the staple food production in Nigeria, combined with an agricultural policy biased against the small-scale producer, caused dramatically increasing imports of cheap rice, wheat, meat, etc., over the past 20 years which hampered the growth of a home market. 


\section{Table 2: Distribution of éfako-units and relative frequency of workers per éfako in four Nupe villages in 1916/26 and 1975/76}

\begin{tabular}{|c|c|c|c|c|c|c|c|c|c|c|}
\hline Time \& & \multicolumn{5}{|c|}{$1916 / 26$} & \multicolumn{5}{|c|}{$1975 / 76$} \\
\hline éfako & Dabba & Lemu & Jima & Kuchi & Total & Dabba & Lemu & Jima & Kuchi & Total \\
\hline $\begin{array}{l}\text { éfako-units as } \\
\% \text { of all } \\
\text { households }\end{array}$ & 61.4 & 51.9 & 56.0 & 55.0 & 57.1 & 28.4 & 23.1 & 28.0 & 35.0 & 26.0 \\
\hline \multicolumn{11}{|l|}{$\begin{array}{l}\text { Male workers } \\
\text { per éfako-unit } \\
\text { (in \%) }\end{array}$} \\
\hline No. 2 & 18.5 & 11.1 & 7.1 & 27.3 & 15.0 & 48.0 & 58.3 & 85.7 & 85.7 & 63.8 \\
\hline 3 & 16.7 & 14.8 & 14.3 & 36.4 & 17.5 & 24.0 & 41.7 & 14.3 & 14.3 & 22.4 \\
\hline 4 & 16.7 & 33.3 & 17.9 & 27.3 & 21.7 & 24.0 & - & - & - & 10.3 \\
\hline 5 & 24.1 & 11.1 & 10.7 & - & 15.8 & 4.0 & - & - & - & 3.4 \\
\hline 6 & 9.3 & - & 25.0 & - & 10.0 & & & & & \\
\hline 7 & 5.6 & - & 3.6 & - & 3.3 & & & & & \\
\hline 8 & 5.6 & 22.2 & 14.3 & - & 10.8 & & & & & \\
\hline 9 & - & - & 7.1 & - & - & & & & & \\
\hline 10 & 1.9 & - & - & - & 0.8 & & & & & \\
\hline 13 & - & 7.4 & - & - & 1.7 & & & & & \\
\hline 16 & 1.9 & - & - & - & 0.8 & & & & & \\
\hline 20 & 1.9 & - & - & - & 0.8 & & & & & \\
\hline \multicolumn{11}{|l|}{ Group size: } \\
\hline - mean: & 4.6 & 5.3 & 5.4 & 4.5 & 4.9 & 2.8 & 2.4 & 2.1 & 2.4 & 2.5 \\
\hline - range: & $2-16$ & $2-13$ & $2-9$ & $2-20$ & $2-20$ & $2-5$ & $2-3$ & $2-3$ & $2-5$ & $2-5$ \\
\hline $\begin{array}{l}\text { No. of éfako- } \\
\text { units: }\end{array}$ & 54 & 27 & 28 & 11 & 120 & 25 & 12 & 14 & 7 & 58 \\
\hline
\end{tabular}

Source: Author's survey, $1976(\mathrm{n}=210)$

Certainly, therefore, a class of landless labourers has not come into being in the villages of Northern Nigeria up to now [cf. Norman et al., 1979: 33, 46-7], but nevertheless the proportion of farmers who were forced by their insufficient resource position to look for paid labour to augment their income has increased considerably in concomitance with world-wide or, at least, national economic cycles, first, during the Korea boom and, second, during the Nigerian oil boom, since the end of the Nigerian Civil War (1970).

We are on the safe side if we assume that hired labour in agriculture, known as aikin kwadago in the North for decades, embraces at least as much (if not more) of the total working force than in both the industrial and urban informal sectors together, where paid labour or aikin batura, that is, 'work of the Europeans', still has the odour of an alien institution [cf. Lubeck, 1979: 313-14]. 
As official statistics which put the proportion of male and female farm labourers in total rural working population as 22.4 per cent and 28.3 per cent [sic] respectively [Rural Economic Survey of Nigeria, Household Enquiry, 1963/64 and 1964/65, Tables VIII, X] are highly unreliable for reasons discussed elsewhere [cf. Kohnert, 1982: 266-80, 393], we have to rely on different agro-economic case studies. The latter indicate that, according to region, on average 16 per cent to 27 per cent of total farm labour in Northern Nigeria during the late 1960s and early 1970s had been done by hired labour [cf. Kohnert, 1982: 156, 393].

Although such average data may give a rough idea of the early stage of development of extended rural commodity production, they are grossly misleading if we want to evaluate the process of social differentiation among the peasantry, as has been shown by a comparative analysis of the predictive capability of different methodological concepts [cf. Kohnert, 1982: 275-84, 333-40]. Concepts of a 'representative' small-scale farmer as well as demographic or life-cycle models do camouflage the process of rural class formation, which is already well under way in Northern Nigeria. Of course, this process is very uneven. A case study of Nupe farmers reveals, for example, that a small class of rich peasants (seven per cent of the sample) commands 21 per cent of the cumulated disposable income of the sample, invested 20 per cent of total capital, and farmed 29 per cent and 12 per cent of the total acreage of marsh and upland respectively (see Table 3). My own and secondary quantitative analysis of Nupe and Hausa peasants have shown in detail that contrary to widespread assumptions about natural (demographic, geographic, or climatic) causes of rural inequality, differences in farm size and income are dominated by the effect of socio-economic variables even in a West African 'land and labour economy'. In addition the importance of class-specific structural differences in the effect of family labour and capital input on farm size or income of rich, middle and poor peasants respectively has been stressed [cf . Kohnert, 1982: 266-362] . The latter has farreaching implications for development planning, as even well-intended (scale-neutral) capital injections into the rural economy (for example, the green revolution) may have adverse effects on the poor peasants.

\section{The transformation of communal and family labour}

The growth of hired labour was directly related to the transition of traditional communal and family labour organisation. First, because it was determinated by the same socio-economic factors mentioned above and, second, because the village community (as far as it still existed), as well as the family, heavily subsidise wage labour. They provide much of the subsistence production for the upkeep of the wage labour force, either during the actual employment of the peasant-worker (by lowering the wages below the necessary product), or during periodic times of unemployment at the slack times of labour demand. 
Table 3: Resource position of different classes in four Nupe villages, 1975/76

(Average values per farm household p.a., and relative frequency per class)

\begin{tabular}{|c|c|c|c|c|c|c|c|c|}
\hline Class & $\begin{array}{l}\text { Rich } \\
\text { peasant }\end{array}$ & & $\begin{array}{l}\text { Middle } \\
\text { peasant }\end{array}$ & & $\begin{array}{l}\text { Poor } \\
\text { peasant/ } \\
\text { Farm } \\
\text { labourer }\end{array}$ & & Total & \\
\hline $\begin{array}{l}\text { Resource Position } \\
\text { Households per class }\end{array}$ & 15 & $7 \%$ & 91 & $43 \%$ & 104 & $50 \%$ & 210 & $100 \%$ \\
\hline No. of residents & 9.7 (b) & & 7.5 & & 117.6 & & 7.7 & \\
\hline $\begin{array}{l}\text { Age of household head } \\
\text { (years) }\end{array}$ & 44.7 & & $41.0(\mathrm{a})$ & & 45.0 & & & 43.2 \\
\hline $\begin{array}{l}\text { Necessary product (1) } \\
\text { (in Naira) }\end{array}$ & 256 & 6 & 253 & 39 & 313 & 55 & 283 & 100 \\
\hline Family-labour days (2) & 176 & 6 & 197 (a) & 38 & 254 & 56 & 224 & 100 \\
\hline Non-family labour days & 264(a) & 30 & 72(a) & 49 & 29 & 22 & 64 & 100 \\
\hline Net-exploitation index (1) & 253(a) & 35 & $52(a)$ & 44 & 22 & 21 & 52 & 100 \\
\hline $\begin{array}{l}\text { Expenditure on non-family } \\
\text { labour (in Naira) }\end{array}$ & $311(a)$ & 27 & 93(a) & 49 & 39 & 24 & 82 & 100 \\
\hline $\begin{array}{l}\text { Expenditure on means of } \\
\text { production (in Naira) }\end{array}$ & 49(a) & 20 & 20(a) & 29 & 11 & 31 & 18 & 100 \\
\hline \multicolumn{9}{|l|}{ Acreage cultivated: } \\
\hline - upland & 12.5 & 12 & 8.0 & 45 & 6.6 & 43 & 7.6 & 100 \\
\hline - fadama & $5.2(\mathrm{~b})$ & 29 & $2.5(\mathrm{a})$ & 60 & 0.7 & 19 & 1.8 & 100 \\
\hline - land value (4) & $28(\mathrm{~b})$ & 16 & 15(a) & 50 & 9 & 34 & 13 & 100 \\
\hline $\begin{array}{l}\text { Households owning fadama } \\
\text { fields (in \%) }\end{array}$ & 93 & & 69 & & 28 & & 50 & \\
\hline $\begin{array}{l}\text { Agricultural net income (in } \\
\text { Naira) }\end{array}$ & 626(b) & 15 & $470(a)$ & 66 & 119 & 19 & 312 & 100 \\
\hline Secondary income (in Naira) (5) & 558 & 41 & $108(a)$ & 48 & 22 & 11 & 98 & 100 \\
\hline Disposable income (in Naira)(6) & 1142(b) & 21 & 573(a) & 63 & 142 & 16 & 410 & 100 \\
\hline Income from rent (in Naira) (7) & (2.4) & & $(0.8)$ & & $(0.0)$ & & & \\
\hline Subsistence index (8) & 53 & & 55 & & 61 & & 58 & \\
\hline $\begin{array}{l}\text { Secondary income as \% of } \\
\text { disposable income }\end{array}$ & 29.9(b) & & 18.5 & & 16.1 & & 18.1 & \\
\hline $\begin{array}{l}\text { Household heads with second.- } \\
\text { school education (in \%) }\end{array}$ & 13 & & 1.1 & & 0.0 & & 1.4 & \\
\hline
\end{tabular}

Note: 1) See for definition, Kohnert [1982].

2) Rough standardized estimates: only the number of family members working on the farm, their sex and age as well as their major tasks during the past agricultural year were asked for; this information was standardized to male adult labour equivalents and multiplied by 138.6, that is, the estimated average number of days per male adult, worked on the family farm p.a. (see Norman [1972:23]; Baldwin [1957:133]; and Kohnert [1982] for a more detailed description).

3) Self-produced means of production, like storage facilities, etc., excluded

4) In 'upland-units': 1 acre fadama $=3$ acres upland

5) Secondary income in kind excluded; 6) income of wives excluded

7) Declared rent only, see text; 8) \% of income in kind of gross household income a) \& b): t-test, separate variance estimate, SPSS-10, 1977 (on-tail prob.)

a) Deviation opposite to next lower class significant at one per cent level,

b) Deviation opposite to next lower class significant at five per cent level.

Source: Author's survey, 1976. 
The prevailing hypothesis concerning the development of gaya is that there exists a trade-off between the increasing use of hired labour and the use of gaya. Kwadago, they say, provides for a better control of the labourer [cf. Smith', 1955: 161], communal work is said to be ineffective and unprofitable [cf. Nwozu, 1975: 88-90; Norman et al., 1972: 2-30], and only suited for subsistence production [cf. Adeniyi, 1972: 109-11; Tiff en, 1972: 378] or villages at the periphery of the economy were traditional communal social relations still prevail [cf. Norman, 1979: 33].

This subsidy of commodity production by subsistence production is a typical sign of the transition of non-capitalist to capitalist forms of rural labour organisation, which already has been observed by Weber [1892] and others in their investigation of the socio-economic setting of peasant-workers and rural labourers in Central and Eastern Europe. But we must be careful to avoid generalisations on the decline of extended family (gandu, in Hausa) or communal labour (gaya, in Hausa). ${ }^{6}$

Although the main line of these arguments may be true for some groups or classes within the countryside it remains nevertheless at the surface of the problem as it characterises only symptoms instead of the underlying articulation of different modes of production: the communal and the capitalist mode of production. During my own research in Nupeland in $1975-76,1$ was quite surprised to see that different kinds of communal labour were still held in high esteem, and some villages, incidentally the most market-orientated, made even more use of this kind of labour than in the past (see Table 1), although one author, who had investigated the region seven years before, reported the incidence of gaya to be near nil [cf. Adeniyi, 1972:107, Table 17]. How could that be explained? Egbe, as the Nupe call this kind of communal labour, was still marked by considerable economies of scale and effectiveness caused by an intense competition between the members participating in the group. According to the opinion of the major potential users, egbe was more profitable for them than kwadago. Depending on the region and task, the employment of egbe groups (about 28 members on average) could save a quarter to one-third of the cost of hired labour (see Kohnert [1982: 16679] for details). Every family which used egbe could extend its family working force, on average, by 57 additional man-days, which was even more welcome as egbe was used mainly to overcome labour bottlenecks during the growing season. But, although the traditional form of organisation of egbe seemed to be left untouched, its contents had changed fundamentally. Again we have to observe class-specific differences.

Egbe use is no longer an indicator of the family size or the age of the family head, but of the wealth of the farmer. Rich peasants and local authorities do not themselves participate any more in the field but send 'lower' members of the family or even pay others to work for them in exchange. A poor peasant, on the other hand, may be obliged to sell his claim to an egbeparty to a third person because his own resource position is too limited for him to make meaningful use of such a sudden inflation of his working capacity. Quite the opposite is true for the landed rich, who are able to employ working groups of 50-100 (in the case of the Emir, even 400) members a day, especially for clearing and weeding, which is the main 
labour bottleneck during the growing season. They would certainly have had difficulties obtaining a reliable short-term supply on the rural labour market at the time. But, also the middle peasants would profit from the liberalisation of traditional rulers of egbe distribution. Distribution is no longer dominated by age and status, but by their own popularity and the working power they are willing to give in exchange. For them, egbe closely resembled the smaller exchange labour groups between friends (dzoro in Nupe) which still observed strict reciprocity. Here, too, I noticed a tremendous growth of the incidence of dzoro over the past six decades (see Table 1), caused mainly by the concomitant decline in the working force of the extended family. However, dzoro takes basically the same direction of development as egbe, including the sale of one's own claims to third parties.

Under such circumstances 'communal labour' is only a covered form of wage labour which undermines its own base. It is foreseeable that the poor will sooner or later sell their labour power direct to the highest bidder, or migrate to the urban areas in the hope of better pay. The employer, on the other hand, particularly if he has a high status and class position, has to pay what is already as much as for hired labour and, that being probably too much for him anyway, he will think about replacing the workers, either by mechanisation or by using herbicides on a large scale, as the Emir of Bida intended the following year, when I asked him about the profitability of his egbe employment.

Much has been written about the dissolution of the extended family unit in Northern Nigeria (see note 6), so it may suffice to summarise the main arguments. According to the prevailing view gandu is a function of demographic factors, namely, the age of the compound head and the life-cycle of the family [see Wallace, 1979: 76; Motion, 1979: 55-64], but Islamisation and modernisation are said to have profound effect on the formation and composition of gandu units. In general a considerable decline has been observed both of the size and incidence of gandu. The rapid expansion of Islam under colonial rule [Annual Colonial Report for 1905/6: 49] led to restrictions concerning both the socio-religious authority of the elders and the customary communal land tenure law; in additional parallel-cousin marriages were not longer tabooed [Greenberg, 1947: 206-9]; this loosened the control of the elders over the exchange of women. But the main factor for the dissolution of gandu farms was the growing inability of the family head to meet the two financial demands which were regarded as essentials of the gandu concept, that is, the payment of bride-price and of tax for all male adults of the gandu [Nadel, 1942: 247]. Increasing outward orientation, due to the new income-earning possibilities that 'modernisation' has brought about, and the wish of the young to escape the rigid paternalistic authority of the elders, was listed among additional determinants of the decline of gandu [Buntjer, 1910;Norman, 1979: 30-1; Goddard, 1973: 215]. However, neither were all peasant households equally affected by this development nor were the backward areas of the North exempted from these changes. On the contrary, whereas the rich could consolidate or even extend their household the poor gandaye had to struggle for survival [Nadel, 1942: 247; Hill, 1972: 61]. 
The results of own investigation among the Nupe may again serve to give an idea of the quantitative dimension of this dissolution process. Whereas two decades after the colonial invasion, during the reign of Etsu Bello (1916-26), over half of the peasant households in the villages investigated still worked in éfako (the Nupe equivalent of gandu), both this proportion and the average size of the éfako groups were reduced to half the size until 1976 (see Table 2). Today at least the incidence of the éfako has to be regarded as a function of wealth: rich peasants have more than double the percentage (47 per cent) of éfako-units as poor peasants ( 21 per cent), and middle peasants were situated in between with 32 per cent [Kohnert, 1982: 184].

Therefore, generalising statements on the future of gandu are misleading unless they refer to certain socio-economic strata or classes. As Tiffen [1972: 105] observed among wealthy cotton farmers of the Gombe Emirate, gandu farms may even increase as 'men may find it easier to pool labour and financial resources, and so to run a larger enterprise, through the traditional family system rather through more formal partnership', like co-operatives or bank loans.

The communal mode of production, based on the production unit of the extended family and institutions of social reciprocity, like communal or exchange labour, had already been weakened by the slave raiding bands in pre-colonial times [cf. Kohnert, 1982: 89-90]. The colonial encounter further undermined this labour organisation by the exploitation and dissolution of the peasantry through a combination of extra-economic and economic force. Thus the subsistence production of the peasant which has been for a long transitional period a main support of the emerging capitalist production, in that it subsidised both wage labour and simple commodity production, has been weakened too.

The decline of the gandu institution also had serious implications for the changing role of women. Although their participation in agricultural production was not as important in the Muslim North as in the South of Nigeria t because of the Islamic practice of wife seclusion, many rural women lost their relative social and economic independence because of the gradual destruction of agricultural sideline occupations. In an investigation of rural Hausa women Simmons came to the conclusion: 'The deprivation of substantial means for earning income will have the effect of downgrading women's independent and family roles, and a new balance will have to be worked out by rural households' [Simmons, 1975: 160]. However, even these implications depended on the socio-economic status of the household to which the women belonged. As a rule the wives of rich peasants could weather the vagaries of capitalist growth better than female members of poor peasant households [Kohnert, 1982: 233-5].

It was not just a specific social organisation which had been destroyed and could be replaced by a new, perhaps more effective, mode of production. The process of destruction also embraced the exchange between man and nature. This became first visible to the Colonial authorities by the end of the Second World War, when the British suddenly woke up to the 
negative impact of their ruthless exploitation of the tin-mines on the fragile ecological balance of the Jos Plateau [Freund, 1981: 156-64]. Non-capitalist household production, which provided for the food and the basic cost of reproduction of the labour in the tin mines, nearly collapsed because of the destruction of the existing forest and grass cover resulting in erosion of the already impoverished soil on a large scale. The socio-economic causes of the persistent Sahel drought [Apeldoorn, 1978] remind us that here we are dealing with a development process which is - though closely interrelated with social conflicts - even more serious, as it may irreversibly endanger the material base for any production.

\section{NOTES}

1. The following draws heavily from an own more detailed study (in German) [Kohnert, 1982: 14584].

2. 'The scheme of taxation aims at providing a modest but sufficient income for the ruling classes, derived from a fair and moderate tax upon the peasantry, thus enabling the former to maintain their position ... and the latter to devote themselves to increasing the output of their land [Lugard, 1907: 17].

3. From 1900 to $1915,42,768$ freed slaves were registered in Northern Nigeria; out of this total 15,701 slaves redeemed themselves. However, these statistics provide a very incomplete picture, as it includes only those cases which, were brought before the courts [cf. 'Freed slaves returns', NAK, SNP 10, 459P/1914, and Resident Kano Province to Sec. North Provinces, Zungeru, 19/7/1915, NAK, SNP $10]$.

4. Still in 1913 about 60,000 porters were employed by the Colonial Government in Northern Nigeria, especially in the tsetse infected Middle Belt [cf. Annual Colonial Report for 1913:20]. 5. For an analysis of famines in Northern Nigeria during the early days of colonial rule [cf. Apeldoorn, 1978; and Hill, 1972: 231, 285]. The famine of 1907 hit especially hard in Nupeland, when the harvest was 50 per cent below average [Annual Colonial Report for 1907/8: 49], it coincided with mass recruitment of railway labour for the Baro-Minna and Jebba-Zungeru line, when according to own estimates [cf. Kohnert, 1982: 152] on the average 20 per cent of the male able-bodied labour force of the villages in the districts concerned had to stay away from their fields. On tax demands in Nupeland [cf. Nadel, 1942: 163-4, 332-47].

6. Cf. Nadel [1942: 248/49] and Hill [1972: 251] for an detailed description of communal labour organisation; and Nadel [1942:27-30, 241-8], Goddard [1973], Butjer [1970], and Hill [1972: 38-56, $249 / 50 ; 1977: 138-43$ ] for an analysis of the change of gandu.

\section{References}

Adeniyi, E. O., 1972, 'A Geographical Analysis of the Population and Rural Economic Development in the Middle Belt of Nigeria: A case Study from Bida and Minna Divisions of Niger Province', Unpublished Ph.D. thesis, University of Ibadan, Dec.

Annual Colonial Reports for Northern Nigeria, London: HMSO, 1901-33.

Apeldoorn, G. J. van, 1978, Drought in Nigeria, Centre for Social and Economic Research, Ahmadu Bello University, 2 vols., Zaria.

Baldwin, K.D.S., 1957, The Niger Agricultural Project, Oxford: Blackwell.

Berthoud, G., 1976, 'Socialité Communautaire et Sociabilité Marchande: De la Richesse a la Pauvreté chez les Ganawuri du Nigeria', in 'L'Ambivalence de la Production. Logiques Communautaires et Logique Capitaliste', Cahiers de I' institut d'Etudes du Développement, Genève, Paris, pp. 17-64. 
Buntjer, B. J., 1970, 'Rural Society in the Zaria Area: The Changing Structure of Gandu'. Reprinted from M. J. Mortimore (ed.), Zaria and its Region, Zaria: Ahmadu Bello University, Occasional Paper, No. 4, pp. 157-70.

Freund, B., 1981, Capital and Labour in the Nigerian Tin Mines, Atlantic Highlands, NJ: Humanities Press.

Goddard, A. D., 1973, 'Changing Family Structures Among the Rural Hausa', Africa, Vol. 43, pp. 20718.

Greenberg, J.H., 1947, 'Islam and Clan Organisation among the Hausa', South-western J. of Anthropology, Vol.3, pp. 193-211.

Grove, A. T., 1957, 'Land and Population in Katsina Province. With Special Reference to Bindawa Village in Dan Yusufu District 1952, Kaduna: Government Printer.

Hill, P., 1977, Population, Prosperity and Poverty: Rural Kano, 1900 and 1970, Cambridge: Cambridge University Press.

Hill, P., 1972, Rural Hausa: A Village and a Setting, Cambridge: Cambridge University Press.

Kohnert, D., 1982, 'Klassenbildung im ländlichen Nigeria. Das Beispiel der Savannenbauern in Nupeland', Institut für Afrika-Kunde, Hamburg.

Lubeck, P., 1979, 'Islam and Resistance in Northern Nigeria', in Goldfrank, W.L. (ed.), The World System of Capitalism: Past and Present, London: Sage, pp. 189-205.

Lugard, F.J.D., 1923, The Dual Mandate in British Tropical Africa, London: Blackwood.

Lugard, F. J.D., 1907, 'Memorandum on the Taxation of Natives in Northern Nigeria', Cd. 3309, London.

Mason, M., 1978, 'Working on the Railway: Forced Labour in Northern Nigeria, 1907-1912', in P. Gutkind et al., (eds.), African Labour History, London: Sage, pp. 56-79.

Matlon, P., 1979, 'Income Distribution Among Farmers in Northern Nigeria: Empirical Results and Policy Implications', African Rural Economy Papers, No. 18, Department of Agricultural Economics, Michigan State University, East Lansing.

Mortimore, M. J., 1973, 'Famine in Hausaland', Savannah, pp. 103-7. National Archives, Kaduna (NAK) files: Bida N.A., and Sec. Northern Provinces.

Nadel, S.F., 1942, A Black Byzantium: The Kingdom of Nupe in Nigeria, Oxford: Oxford.

University Press (reprint 1973).

Norman, D.W., 1979, et al., 'Technical Change and the Small-Scale Farmer in Hausaland, Northern Nigeria.' African Rural Economy Papers, No.21, Department of Agricultural Economics, Michigan State University, East Lansing.

Norman, D. W., et al., 1972, 'An Economic Survey of Three Villages in Zaria Province', 2. InputOutput Study, Vol. 1, Text, Samaru Miscellaneous Paper, No. 37, Zaria.

Nwosu, A.C.A., 1975, 'An Economic Analysis of Production and Resource-Use Efficiency in Kwara State Peasant Agriculture', unpublished M.Sc. thesis, Department of Agricultural Economics, University of Ibadan.

Patnaik, U., 1979, 'Neo-Populism and Marxism: The Chayanovian View of the Agrarian Question and its Fundamental Fallacy', Journal of Peasant Studies, Vol. 6, pp. 375-420.

Prothero, R.M., 1957, 'Migratory Labour from North-Western Nigeria', Africa, Vol.27, pp.251-61. Rural Economic Survey of Nigeria, 1966, 'Household Enquiry 1963/64 and 1964/65', Federal Office of Statistics, Lagos.

Simmons, E.B., 1975, 'The Small-Scale Rural Food Processing Industry in Northern Nigeria', Food Research Institute Studies, Vol. 14, pp. 147-62.

Smith, M. G., 1955, 'The Economy of Hausa Communities of Zaria', Colonial Research Studies, No. 16, London: HMSO.

Tiffen, M., 1972, 'The Enterprising Peasant: A Study of the Agents of and Constraints on Agricultural Development in Gombe Emirate, North Eastern State, Nigeria', Interim Report for the Overseas Development Administration, London.

Wallace, T., 1979, 'Rural Development Through Irrigation: Studies in the Town on the Kano River Project', Centre for Social and Economic Research, ABU, Zaria.

Weber, M., 1892, 'Die Verhältnisse der Landarbeiter im ostelbischen Deutschland', Schriften des Vereins für Sozialpolitik, Bd. 55, Leipzig. 